\section{A public for Celltech?}

To cap a flurry of recent announcements from Britain's leading biotechnology company, Celltech, Gerard Fairtlough, its chief executive, said last week that it is "entirely possible" that the company will go public within five years. In the meantime, it needs to find new admirers among financial institutes both to provide additional capital and to replace the British Technology Group (which next week will announce the formation of a new biotechnology company) in its measured withdrawal as the major shareholder.

Fairtlough sees no problem in finding new investors, and as evidence of Celltech's viability, he points to the advanced plans for setting up BootsCelltech Diagnostics Limited and the opening this week of a Culture Products Division of Celltech.

The new division has the task of bulk production of monoclonal antibodies. Some, such as interferon and ABO blood group monoclonals, are for Celltech to sell. Others are on contracts, about six of which have been negotiated with companies that include ICI and Centocor, at around $£ 500$ per gramme of antibody for quantities of less than $1 \mathrm{~kg}$.

The division has at present two 100-litre fermenters in which a batch of antibodyproducing hybridoma cells can be grown every week or so. With a $£ 100,000$ grant from the British Government's Department of Industry, Celltech expects soon to be able to develop a pilot-scale continuousculture fermenter in which hybridoma cells will survive and produce antibody for several months at a time.

It also claims that, contrary to many opinions, rodent hybridoma cells are perfectly capable of growing in suspension rather than in the protected environment of capsules or fibres and that the yield of antibody from such cells is several hundred microgrammes per millilitre, an order of magnitude greater than had been thought possible. Celltech is confident that human hybridoma cells will behave just as well. And it claims to be in the final stages of development of a serum-free medium in which to suspend the cells during fermentation.

Celltech's plan to make money out of the genetic mapping of microorganisms on contract is, however, going less well. The procedure was devised in Dr Sydney Brenner's Medical Research Council (MRC) laboratory in Cambridge, but its development into a commercial process is "much slower than hoped".

The future of the agreement whereby Celltech has first rights of refusal on any MRC invention in the area of recombinant DNA or monoclonal antibody research is also up for grabs. Fairtlough, usurprisingly, would like it to continue and believes MRC has been delighted so far.
The agreement runs until 1985 but is now being reviewed. One crucial factor is whether MRC will wish to carry on. Another is whether Celltech will be able to secure first rights even in a circumscribed area when the National Research Development Corporation, originally a reluctant partner in the arrangement, and which collects a rent from Celltech to cover loss of benefit, is soon to lose its first claim on research council research. Most probably, the monogamous agreement between Celltech and MRC will turn into an agreement that is polygamous on both sides.

Peter Newmark

\section{Satellite storm ahead}

\section{Washington}

BRITAIN is adding its voice to the chorus of domestic criticism of the Reagan Administration's plan to sell the government's remote sensing and weather satellites to private business. A frosty memorandum spelling out the British attitude warns that the sale could damage scientific cooperation between the two countries and could have "serious repercussions" on international weather forecasting.

The memorandum, which has been made available to the congressional committees concerned, describes the free exchange of meteorological information between national weather services as a "fundamental principle"' which should be safeguarded in any arrangement the United States makes to sell its satellites to private operators. If the United States began to charge for its satellite observations, the British note claims, other countries would follow suit.

Britain is also worried about the impact of a sale on an agreement to provide instruments for the United States' polar-orbiting meteorological satellites. The United Kingdom Meteorological Office already provides stratospheric sounding units for the American TIROS-N satellites in exchange for free data from the satellites. In recent months, the two countries have agreed in principle to extend the arrangement, with Britain providing an advanced microwave sounding unit.

The British memorandum expresses less concern about the fate of the remote sensing satellites, but says it is "doubtful" whether the time is ripe for the wholesale commercialization of such systems. Pointing out that individual British research laboratories are working as principal investigators on remote sensing with the National Aeronautics and Space Administration, it says the United Kingdom would be "very concerned" if the proposed changes led to a reduction in similar opportunities for collaboration. Peter David
Spanish research

Discreet threat about jobs

\section{Barcelona}

THE newly appointed president of CSIC (Consejo Superior de Investigaciones Cientificas, the Spanish science research council) has made an increase in CSIC personnel his "absolutely priority" task and intends to make it a condition of his continuing in his job. Other points that he stressed in his first speech were a contraction in the number of lines of research carried out by CSIC institutes and the need to consider the possible transfer of the CSIC institutes to the autonomous governments now established in the different parts of Spain.

Dr Jose Elguero Bertolini is the first CSIC scientist with considerable scientific experience abroad to have been appointed president of CSIC, a job traditionally given to a university professor. An organic chemist, he has spent most of his career in France. His scientific and international experience will be very useful in the present move to redefine the function of CSIC.

In the first declaration on science policy by a member of the government since it took office eight months ago, Mr José Maravall, the Minister of Education and Science, echoed in a speech to the Senate much of what Dr Elguero said. He confirmed the intention of the Socialist Government to increase public spending on research. He stressed the need to reorganize the structure of organizations concerned with science policy in Spain, to propose a number of priority research fields and to define the place for research in the new structure of the Spanish state, with its 17 autonomous governments. Four fields of research to be given priority in conjunction with Spanish industry are energy use of biomass, aquaculture, microelectronics and railway technology. Two broad fields have been chosen for priority financing in basic research: high-energy physics, which will be immediately affected by the recent reentering of Spain into the European Organization for Nuclear Research (CERN), and biotechnology.

The promised increase in public spending on research has already begun, and CSIC this year has 21 per cent more money. The government's general policy, however, is directed to reducing public expenditure, particularly on administrative staff, and if that policy is applied to research, the effect of the new funds would be very much reduced. The scientific staff of CSIC has not been increased for many years and it is now reaching an average age of 48 , while many young scientists in Spain and abroad are anxious to join the new Spanish effort on science. CSIC is keeping its fingers crossed that its new president will have no reason to resign soon.

Pedro Puigdoménech 